\title{
sciendo
}

DOI 10.2478/sbe-2021-0053

SBE no. 16(3) 2021

\section{CORPORATE GOVERNANCE ATTRIBUTES AND ACCOUNTING CONSERVATISM: EVIDENCE FROM CHINA}

\section{PASKO Oleh}

Sumy National Agrarian University, Ukraine

\author{
CHEN Fuli
}

Henan Institute of Science and Technology, China

Sumy National Agrarian University, Ukraine

\section{BIRCHENKO Nataliia}

Kharkiv Petro Vasylenko National Technical University of Agriculture, Ukraine

\section{RYZHIKOVA Natalia}

Kharkiv Petro Vasylenko National Technical University of Agriculture, Ukraine

\begin{abstract}
:
The paper explores the association between corporate governance attributes and the extent of accounting conservatism apparent in Chinese listed companies' financial reporting. The findings demonstrate that significant positive association exists between board independence, board size and accounting conservatism in Chinese information technology companies. Conversely, CEO duality, management shareholding and the shareholding ratio of the largest shareholder significantly negatively correlated with accounting conservatism. To the best of the author's knowledge, this is one of the first empirical papers revealing the evidence on the relationship between corporate governance attributes and accounting conservatism in China. Overall, the author's findings match up with the assertion that accounting conservatism assists directors in reducing agency costs of firms.
\end{abstract}

Key words: China, corporate governance, accounting conservatism, board structure, ownership structure

\section{Introduction}

According to the agency theory, there is a problem of agent behaviour caused by the separation between management and ownership (Jensen \& Meckling, 1976; Vitolla, Raimo, \& Rubino, 2020). Managers, although they should serve shareholders, due to that separation got much of leeway in running the company, which could be used to further private interests in a way detrimental to those of shareholders. Moreover, shareholders 
unable to follow the company's affair daily and as a result, they do not have the same amount of information acquired by managers and that consequently leads to asymmetry of information problem. Shareholders, primarily, accrue information like many other outside users, from the firm's published financial statements produced by management. Prior researches have shown that corporate governance system employed and financial reporting mechanisms could be seen as a means of reducing agency costs and ensuring that the firm's resources are used in a manner consistent with shareholder goals (Cullinan, Wang, Wang, \& Zhang, 2012; García Lara, Osma, \& Penalva, 2007; Lim, 2011; Mubeen, Han, Abbas, \& Hussain, 2020; Shleifer \& Vishny, 1986; Vitolla et al., 2020).

One of the characteristics of accounting information from ancient times was conservatism (Basu, 1997). Accounting conservatism is known to be one of the tools to reduce the asymmetry of information between managers and shareholders, thus reducing agency costs and helping to better protect shareholders and achieve their objectives (García Lara, García Osma, \& Penalva, 2009; Gillan, 2006; Nguyen, Duong, Nguyen, \& Bui, 2020). There is strong support in the literature for the suggestion that conservatism is an irreplaceable tool for monitoring management (Ahmed \& Duellman, 2007; Ahmed \& Henry, 2012; Chi, Liu, \& Wang, 2009; Chung, Firth, \& Kim, 2003; Elshandidy \& Hassanein, 2014; Nasr \& Ntim, 2018). It is believed that a weak board that do not act in shareholders' best interests is a reason behind the non-use of conservative accounting (Caskey \& Laux, 2017). Conservatism and corporate governance serve the same goal - to reduce the information asymmetry (Ahmed \& Duellman, 2007; Cullinan et al., 2012; García Lara et al., 2007). As Cullinan et al. state "accounting conservatism can serve as a mechanism to balance the interests of managers and shareholders and to reduce the effects of information asymmetry" (Cullinan et al., 2012, p. 1)

Conservatism is seen as a significant attribute of companies and is believed tightly connected to corporate governance (Ahmed \& Duellman, 2007). As Lim fittingly put it "corporate governance complements conservatism in that it promotes conservative accounting being adopted in financial reporting" (Lim, 2011, p. 1008). Influence of conservatism in accounting has a long history and probably is to remain one of the features of accounting in future. Basu 1997, for example, avers that the reporting practice has been influenced by conservatism for the last 500 years (Basu, 1997), Sterling named it one of the most important principles of evaluation in accounting (Sterling, 1967) and Watts suggests that reporting practice not only is conservative but has become more conservative in the last 30 years (Watts, 2003, p. 208). Concerning corporate governance "conservative accounting is desirable because it allows the board of directors to better oversee the firm's investment decisions" (Caskey \& Laux, 2017). Just recently conservatism was praised as "a mechanism to mitigate the same agency problem" and "mitigating agency costs arising from free cash flows" (Lobo, Robin, \& Wu, 2020, p. 728). Furthermore, Bolgorian and Mayeli based on data from Iran concluded that "more conservative firms are less likely to be involved in money laundering activities" (Bolgorian \& Mayeli, 2020).

Conservative accounting safeguards from alleviates and lowers potential earnings manipulation by transactional managers who nine times out of ten manipulate earnings by inflating it and through it resort to aggressive accounting - the very opposite phenomenon 
to conservatism (Lim, 2011; Nasr \& Ntim, 2018; Yang \& Ko, 2019). Corporate governance goes hand in hand with conservatism as it also prioritizes conservative accounting as opposed to aggressive.

Previous research on corporate governance has focused mainly on finding out whether there is a link between corporate governance and a company's financial performance. Although there is an abundance of such studies findings so far are mixed. We, following some others author (like Ahmed \& Duellman, 2007; Lim, 2011), argue that there is a logical trap in that research construction and this trap is the effect of conservatism itself. The logical chain behind our statement is simple: companies that strive to match all the requirements of good corporate governance tend to take a more conservative approach to the reporting, hence they report lower profits, which in turn leads to the perception of this as insufficient financial performance. Therefore, an examination of the linkage corporate governance - financial performance "will be biased downward" (Lim, 2011, p. 1008).

The relationship of corporate governance with accounting conservatism has not been as extensively researched into as that of corporate governance and financial performance. Prior papers, for the most part, concentrated on a single element of corporate governance, namely, board characteristics or ownership structure (Ahmed \& Duellman, 2007; Ahmed \& Henry, 2012; Chi et al., 2009; Cullinan et al., 2012; Elshandidy \& Hassanein, 2014; Kukah, Amidu, \& Abor, 2016; Lim, 2011; Nasr \& Ntim, 2018), the impact of international financial reporting standards (IFRS) on accounting conservatism (Elshandidy \& Hassanein, 2014), banking expertise on the board (Moy, Heaney, Tarca, \& van Zyl, 2020) or some aggregate indexes combining multiple indicators (García Lara et al., 2007). The findings so far are at best inconclusive as researchers came to a contrasting conclusion. For example, Ahmed \& Duellman studying accounting conservatism in US-listed firms and García Lara et al. in Spanish listed firms came to the conclusions that corporate governance attributes positively associated with accounting conservatism (Ahmed \& Duellman, 2007; García Lara et al., 2007). However, the paper by Chi et al. conducted in Taiwan shows that corporate governance attributes negatively associated with accounting conservatism (Chi et al., 2009). All these contradictory results in various jurisdictions may hint that the findings are sensitive to institutional settings. If the results depend on the institutional environment in the jurisdiction, then it follows that the results of a study in one country may not be applicable in another simply because of a difference in institutional settings.

Against this background, our study focuses on studying corporate governance attributes impact on accounting conservatism in 309 listed information technology companies in China, with a total of 2154 firm-year observations covering 2003 to 2019 years. The major corporate governance attributes we are focusing on in this paper are board independence, the board size, CEO duality, management shareholding, the shareholding ratio of the largest shareholder. Unlike much previous research concentrated on rather one attribute (board characteristics or ownership structure) our study combines research on both board structure and ownership structure.

Therefore, our study aims to contribute to the literature in several distinctive ways. First, to the best of our knowledge, it offers the first-ever empirical examination of the link 
between board attributes and accounting conservatism in the Chinese listed companies (although the link between ownership structure and accounting conservatism in China studied by Cullinan et al., 2012). Second, given the abovementioned, our study makes new insight which either corroborates or negates the previous studies' findings in understudied, in that regard, jurisdiction. The paper's findings could also be utilized by policymakers and regulators alike in guiding their decision-making process in an effort to enhance corporate governance practice on the ground. This study might too arouse interest in investors who may be looking for the clues of how reporting practices may vary across borders, and how various institutional settings are implicated in accounting conservatism.

The remainder of the paper is organized as follows. Section 2 analyses relevant literature and proposes the hypothesis that will be exposed to testing in further sections. Section 3 reveals the data selection process and sampling of the study as well as depicts the variables used. The penultimate section presents the results gained as a consequence of the empirical testing of the hypothesis. The paper closes with discussions of the findings and conclusions.

\section{Literature review and hypothesis development}

\subsection{What is accounting conservatism?}

Accounting conservatism is measured as "the on average understatement of the book value of net assets relative to their market value" (Beaver \& Ryan, 2005, p. 269). Accounting conservatism is rooted partly in tradition and partly in behaviour and is defined by some authors as "the accountant's tendency to require a higher degree of verification to recognize good news as gains than to recognize bad news as losses" (Basu, 1997, p. 4), although some interpret conservatism more broadly as "accountants' preference for accounting methods that lead to lower reported values for shareholders' equity" (Basu, 1997, p. 8). As the field evolved the more mature definition emerged which linked conservatism with timeliness. For example, Guay and Verrecchia define conservatism as: "More timely recognition of losses than gains as a result of the costs and benefits of reporting verifiable information by managers and/or firms being asymmetric" (Guay \& Verrecchia, 2006, p. 149).

As you might have noted two issues are to be highlighted here. Firstly, there is a trade-off between verifiability of information and its timeliness and, secondly, this trade-off is approached differently depending on whether it is applied to losses or gains (Barker \& McGeachin, 2015). The trade-off between verifiability of information and its timeliness is resolved in favour of verifiability at the expense of timeliness until the proper or satisfied level of verifiability reached. That is why 'asymmetric timeliness' of recognition plays a crucial role here. As a matter of fact, accounting conservatism is an asymmetric recognition of gains and losses because "a higher standard of verifiability for recognition of gains than for losses" (Watts, 2006, p. 52).

However, the feature of conservatism in accounting is not that losses are recognized in a more timely manner, but that the recognition of gains is delayed (Guay \& Verrecchia, 
2006). From this one can infer that "the greater the difference in degree of verification required for gains versus losses, the greater the conservatism" (Watts, 2003, p. 208).

In closing, although the literature has not yet reached one unanimously approved definition of conservatism, "a common implication of the different notions of conservatism appears to be that on average book values are understated" (Rajan, Reichelstein, \& Soliman, 2007, p. 326). Conservatism is seen as a positive phenomenon throughout the literature because it perceived as "a mechanism for enhancing the credibility of financial reporting by means of reducing the subjective, opportunistic reporting of gains" (Barker and McGeachin 2015) and last but not least because it "benefits users of the firm's accounting reports" (Watts 2003, 209).

\subsection{Summary of prior studies on the effect of corporate governance attributes on accounting conservatism}

Generalizations of the results of previous studies of the relationship between corporate governance and accounting conservatism are presented in Tables 1 and 2.

Table 1: Prior studies on the effect of corporate governance attributes on accounting conservatism*

\begin{tabular}{|c|c|c|c|c|}
\hline Authors & $\begin{array}{l}\text { Dependable } \\
\text { variables }\end{array}$ & $\begin{array}{c}\text { Corporate } \\
\text { governance } \\
\text { attributes } \\
\end{array}$ & Sample & Main findings \\
\hline \multirow{4}{*}{$\begin{array}{l}\text { (Ahmed \& } \\
\text { Duellman, } \\
2007 \text { ) }\end{array}$} & \multirow{4}{*}{$\begin{array}{l}\text { Accounting } \\
\text { conservatism }\end{array}$} & Board size & \multirow{4}{*}{$\begin{array}{l}200 \text { US-listed } \\
\text { firms (1999- } \\
2000)\end{array}$} & $\begin{array}{c}\text { No significant relation with } \\
\text { conservatism }\end{array}$ \\
\hline & & $\begin{array}{l}\text { Insiders on the } \\
\text { board }\end{array}$ & & -ve relation with conservatism \\
\hline & & $\begin{array}{c}\text { Separation of } \\
\text { chairman/CEO }\end{array}$ & & $\begin{array}{c}\text { No significant relation with } \\
\text { conservatism }\end{array}$ \\
\hline & & $\begin{array}{l}\text { Outside director } \\
\text { ownership }\end{array}$ & & +ve relation with conservatism \\
\hline $\begin{array}{l}\text { (García Lara et } \\
\text { al., 2007) }\end{array}$ & $\begin{array}{l}\text { Accounting } \\
\text { conservatism }\end{array}$ & $\begin{array}{c}\text { Strong governance } \\
\text { characteristics } \\
\text { (aggregate index) }\end{array}$ & $\begin{array}{l}69 \text { Spanish } \\
\text { listed firms } \\
(1997-2002)\end{array}$ & +ve relation with conservatism \\
\hline \multirow{4}{*}{$\begin{array}{l}\text { (Chi et al., } \\
\text { 2009) }\end{array}$} & \multirow{4}{*}{$\begin{array}{l}\text { Accounting } \\
\text { conservatism }\end{array}$} & Board size & \multirow{4}{*}{$\begin{array}{c}4,181 \\
\text { Firms- year } \\
\text { observation } \\
\text { from Taiwan. } \\
(1996-2004)\end{array}$} & $\begin{array}{c}\text {-ve significant relation with } \\
\text { conservatism }\end{array}$ \\
\hline & & Board expertise & & $\begin{array}{c}\text {-ve significant relation with } \\
\text { conservatism }\end{array}$ \\
\hline & & CEO duality & & $\begin{array}{c}\text { +ve significant relation with } \\
\text { conservatism }\end{array}$ \\
\hline & & $\begin{array}{l}\text { Institutional } \\
\text { ownership }\end{array}$ & & $\begin{array}{l}\text { +ve significant relation with } \\
\text { conservatism }\end{array}$ \\
\hline \multirow{5}{*}{ (Lim, 2011) } & \multirow{5}{*}{$\begin{array}{l}\text { Accounting } \\
\text { conservatism }\end{array}$} & Board size & \multirow{5}{*}{$\begin{array}{l}644 \text { Australian } \\
\text { firms in (1998) } \\
\text { and } 774 \text { in } \\
(2002)\end{array}$} & $\begin{array}{l}\text { No statistical association with } \\
\text { cons }\end{array}$ \\
\hline & & $\begin{array}{l}\text { Independent } \\
\text { directors }\end{array}$ & & $\begin{array}{l}\text { No statistical association with } \\
\text { cons }\end{array}$ \\
\hline & & CEO duality & & $\begin{array}{l}\text { Weak -ve association with } \\
\text { conservatism }\end{array}$ \\
\hline & & Big 4 auditors & & + ve relation but not significant \\
\hline & & $\begin{array}{l}\text { Independent } \\
\text { directors on } A C\end{array}$ & & $\begin{array}{l}\text { Weak +ve relation with } \\
\text { accounting cons }\end{array}$ \\
\hline (Ahmed \& & Accounting & Board size & 120 Australian & +ve relation with conservatism \\
\hline
\end{tabular}


Studies in Business and Economics no. $x(Y) / 2020$

\begin{tabular}{|c|c|c|c|c|}
\hline \multirow[t]{2}{*}{ Henry, 2012) } & \multirow[t]{2}{*}{ conservatism } & $\begin{array}{l}\text { Independent } \\
\text { directors }\end{array}$ & \multirow[t]{2}{*}{$\begin{array}{l}\text { listed firms } \\
(1992-2002)\end{array}$} & +ve relation with conservatism \\
\hline & & Audit committee & & +ve relation with conservatism \\
\hline \multirow{3}{*}{$\begin{array}{l}\text { (Cullinan et al., } \\
\text { 2012) }\end{array}$} & \multirow{3}{*}{$\begin{array}{l}\text { Accounting } \\
\text { conservatism }\end{array}$} & $\begin{array}{l}\text { largest shareholder } \\
\text { influence }\end{array}$ & \multirow{3}{*}{$\begin{array}{l}\text { Chinese listed } \\
\text { firms, } 3646 \text { firm- } \\
\text { year } \\
\text { observations } \\
\text { (2007 to } 2009 \text { ) }\end{array}$} & $\begin{array}{l}\text {-ve relation to the degree of } \\
\text { influence held by the largest } \\
\text { shareholder }\end{array}$ \\
\hline & & $\begin{array}{l}\text { controlling } \\
\text { shareholder }\end{array}$ & & $\begin{array}{l}\text {-ve relation to the presence of } \\
\text { a controlling shareholder }\end{array}$ \\
\hline & & $\begin{array}{l}\text { large shareholders } \\
\text { (other than the } \\
\text { largest } \\
\text { shareholder) }\end{array}$ & & no association \\
\hline \multirow{3}{*}{$\begin{array}{l}\text { (Elshandidy \& } \\
\text { Hassanein, } \\
\text { 2014) }\end{array}$} & \multirow{3}{*}{$\begin{array}{l}\text { Accounting } \\
\text { conservatism }\end{array}$} & Board size & \multirow{3}{*}{$\begin{array}{l}72 \text { UK listed } \\
\text { firms (2002- } \\
2007)\end{array}$} & $\begin{array}{l}\text { No significant relation with } \\
\text { conservatism }\end{array}$ \\
\hline & & $\begin{array}{l}\text { Board } \\
\text { independence }\end{array}$ & & $\begin{array}{l}\text { +ve significant relation with } \\
\text { conservatism }\end{array}$ \\
\hline & & $\begin{array}{l}\text { Separation of } \\
\text { chairman/CEO }\end{array}$ & & $\begin{array}{l}\text { +ve significant relation with } \\
\text { conservatism }\end{array}$ \\
\hline \multirow{4}{*}{$\begin{array}{l}\text { (Nasr \& Ntim, } \\
\text { 2018) }\end{array}$} & \multirow{4}{*}{$\begin{array}{l}\text { Accounting } \\
\text { conservatism }\end{array}$} & board size & \multirow{4}{*}{$\begin{array}{l}67 \text { listed } \\
\text { Egyptian } \\
\text { companies } \\
(2015)\end{array}$} & $\begin{array}{l}\text { significant -ve relationship } \\
\text { with conservatism }\end{array}$ \\
\hline & & $\begin{array}{l}\text { board } \\
\text { independence }\end{array}$ & & $\begin{array}{l}\text { significant +ve relationship } \\
\text { with conservatism }\end{array}$ \\
\hline & & $\begin{array}{l}\text { separation of } \\
\text { chairman and CEO } \\
\text { roles }\end{array}$ & & $\begin{array}{l}\text {-ve but insignificant } \\
\text { relationship with conservatism }\end{array}$ \\
\hline & & Big 4 auditors & & $\begin{array}{l}\text { significant -ve relationship } \\
\text { with conservatism }\end{array}$ \\
\hline
\end{tabular}

*Source: Compiled by the authors based on (Nasr \& Ntim, 2018) and own investigation

Table 2: Summary of corporate governance attributes studied and its effect on accounting conservatism

\begin{tabular}{|c|c|c|c|c|c|c|c|c|c|c|c|}
\hline & & & & & $\stackrel{\sim}{\check{N}}$ & $\frac{\widetilde{N}}{\mathrm{O}}$ & $\stackrel{\mathbb{T}}{+}$ & $\stackrel{\infty}{\infty}$ & \multicolumn{3}{|c|}{ In total } \\
\hline & 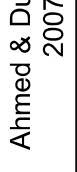 & 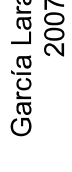 & $\begin{array}{l}\frac{i}{\pi} \\
\frac{\pi}{0} \\
\frac{\bar{c}}{0}\end{array}$ & $\begin{array}{l}\text { ㄱ } \\
\dot{E}\end{array}$ & $\begin{array}{l}\frac{1}{\Phi} \\
\frac{1}{\infty} \\
0 \\
\Phi \\
\frac{\Phi}{C} \\
\frac{1}{<}\end{array}$ & $\begin{array}{l}\frac{\pi}{ \pm} \\
\frac{1}{0} \\
\frac{1}{0} \\
\overline{\bar{J}} \\
\stackrel{U}{U}\end{array}$ & 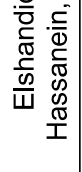 & $\begin{array}{l}\frac{.5}{ \pm} \\
\infty \\
\frac{1}{2} \\
\frac{1}{\pi} \\
Z\end{array}$ & + & - & • \\
\hline Board size & $\bullet$ & & - & $\cdot$ & + & & - & - & 1 & 2 & 3 \\
\hline Board independence & & & & $\bullet$ & + & & + & + & 3 & 0 & 1 \\
\hline Insiders on the board & - & & & & & & & & 0 & 1 & 0 \\
\hline Board expertise & & & - & & & & & & 0 & 1 & 0 \\
\hline $\begin{array}{l}\text { Separation } \\
\text { chairman/CEO }\end{array} \quad$ of & • & & + & - & & & + & - & 2 & 2 & 1 \\
\hline Big 4 auditors & & & & + & & & & - & 1 & 1 & 0 \\
\hline Audit committee & & & & & + & & & & 1 & 0 & 0 \\
\hline $\begin{array}{l}\text { Independent directors on } \\
\text { AC }\end{array}$ & & & & + & & & & & 1 & 0 & 0 \\
\hline $\begin{array}{ll}\text { Outside } & \text { director } \\
\text { ownership } & \\
\end{array}$ & + & & & & & & & & 1 & 0 & 0 \\
\hline Institutional ownership & & & + & & & & & & 1 & 0 & 0 \\
\hline $\begin{array}{l}\text { Strong } \quad \text { governance } \\
\text { characteristics (aggregate } \\
\text { index) }\end{array}$ & & + & & & & & & & 1 & 0 & 0 \\
\hline largest shareholder & & & & & & - & & & 0 & 1 & 0 \\
\hline
\end{tabular}




\begin{tabular}{|l|l|l|l|l|l|l|l|l|l|l|l|}
\hline influence & & & & & & & & & & & \\
\hline controlling shareholder & & & & & & - & & & 0 & 1 & 0 \\
\hline $\begin{array}{l}\text { large shareholders (other } \\
\text { than the largest } \\
\text { shareholder) }\end{array}$ & & & & & & - & & & 0 & 0 & 1 \\
\hline
\end{tabular}

Source: Compiled by authors. + positive; - negative; - - no association.

The first conclusion that can be drawn from these data is that research in this area is insufficient as only a few papers could be referred to. Compared to other areas where the effect of corporate governance is studied it is a drop in the ocean. The second very important conclusion is that the results presented are inconclusive and contradicting. The third remark derived from the data is concerning the type of law system in the jurisdiction studied. Four studies have been done in common law jurisdictions (US, UK, Australia), two - in code law surrounding (Spain, Taiwan) and only two in the emerging economy country (China, Egypt).

Based on the results of the literature analysis, we decided to explore five attributes of corporate governance, namely, board independence, board size, CEO duality, management shareholding and the shareholding ratio of the largest shareholder. We considered also six attributes - Big 4 auditors - but we skipped it because only $3.3 \%$ of the companies in the information technology industry in China - our sample - are audited by the Big Four accounting firms each year, which is not significant in the correlation and regression analysis. Our overarching hypothesis is that firms with stronger corporate governance will demonstrate a higher degree of accounting conservatism.

\subsection{Hypothesis development}

\section{Board independence and accounting conservatism}

The board of directors plays a leading role in corporate governance. Although the board of directors plays a vital role in every company often in calm times its impact goes undetected. But then things go wrong they find themselves at the forefront of the events, which is attested in cases of Enron, Worldcom, and Parmalat scandals (Adams, Hermalin, \& Weisbach, 2010).

Shareholders hire a board of directors to ensure that hired managers work in their best interest, in a way that enhances their well-being. In turn, an effective board of directors will ensure that management adopts and adheres to conservative accounting, which will prevent excessive payments, including in the form of management compensation. An important feature of an effective board of directors is its independence, which is already included in almost all corporate governance codes. The independence of the board of directors, including from the managers, is crucial as it allows the former to better control the latter. Several authors' findings confirm that the independent boards adopt more conservative accounting (Ahmed \& Henry, 2012; Elshandidy \& Hassanein, 2014; Nasr \& Ntim, 2018). On contrary Ahmed \& Duellman found that there is a negative association, whilst Lim concluded that there is no association at all (Ahmed \& Duellman, 2007; Lim, 2011). Therefore, the following hypothesis is proposed.

Hypothesis 1: Board independence is positively associated with conservative accounting. 


\section{Board size and accounting conservatism}

Previous research indicates that the optimal group size depends on several factors inherent in the group and the tasks that this group must perform (Ali \& Ayoko, 2020; Khuong et al., 2020). Simple logic suggests, and research confirms, that small boards of directors are easier to control and coordinate (Jensen, 1993), and small boards of directors have fewer incidents of free-rider problems (Hermalin \& Weisbach, 2003). Instead, large boards of directors are more likely to have more experienced directors (Ali \& Ayoko, 2020; Chowdhury \& Wang, 2020; Xie, Davidson, \& DaDalt, 2003). Besides, in large boards, directors may have an appropriate division of responsibilities and, consequently, they may be more focused on what they understand best (Ahmed \& Duellman, 2007). At the same time, in large boards, the risk of rupture lines (internal division) is much higher than in small ones because "group size has implications for the formation of faultlines because size facilitates the desire for subgroup interactions" (Ali \& Ayoko, 2020, p. n.a)

Previous studies have yielded inconsistent results. Ahmed \& Henry found positive association based on the study of Australian companies (Ahmed \& Henry, 2012). Ahmed \& Duellman and Lim based on the study of US and Australian companies prospectively came to the conclusion that there is no association (Ahmed \& Duellman, 2007; Lim, 2011). Chi et al., and Nasr \& Ntim according to the results of research conducted based on Taiwanese and Egyptian companies found a negative association (Chi et al., 2009; Nasr \& Ntim, 2018).

Successful boards are more prone to adhere to more conservative accounting. Therefore, the following hypothesis is put forward:

Hypothesis 2: Board's size is positively associated with conservative accounting.

\section{CEO duality and accounting conservatism}

The problem with CEO duality is well-rooted in agency and stewardship theories (Mubeen et al., 2020). The natural state of affairs, according to the agency theory, is the dispensation of the positions of CEO and chairman of the board of directors. After all, if there is a fusion of positions, there is a situation where the chairman of the board may be on the side of management, not shareholders. This risk from the standpoint of the agency theory clearly indicates the need for the distribution of these roles (Ozbek \& Boyd, 2020). CEO duality declines board powers and puts constraints on board independence (lyengar \& Zampelli, 2009; Mubeen et al., 2020). "A board of directors chaired by the CEO is likely to be dominated by the CEO and hence to be ineffective in performing its duties" (Lim, 2011, p. 1012). The empirical study though point to the positive role of CEO duality on financial performance due to its "positive effect on market competition and market competition fully mediates the impact of CEO duality on firm performance" (Mubeen et al., 2020, p. 14).

Studies concerning the link between accounting conservatism and CEO duality revealed vacillating findings. Chi et al. and Elshandidy \& Hassanein found positive association (Chi et al., 2009; Elshandidy \& Hassanein, 2014), whereas Lim and Nasr \& Ntim negative association (Lim, 2011; Nasr \& Ntim, 2018) and Ahmed \& Duellman no 
association at all (Ahmed \& Duellman, 2007). Thus, based on the proposition of the theory agency and previous research, we proceed with this hypothesis as follows.

Hypothesis 3: CEO duality is negatively associated with accounting conservatism.

\section{Management shareholdings and accounting conservatism}

Management shareholding measured as the share of the share belonging to the management to the total number of shares. The proposition here is that "the more managers own shares in the company, the lower the tendency of managers manipulating the earnings of the firm, since any such move would affect their own shareholdings as well" (Kukah et al., 2016, p. 47). Thus, we expect a positive association between managerial ownership and accounting conservatism which is promulgated in the next hypothesis:

Hypothesis 4: Management shareholding is positively associated with accounting conservatism.

\section{The shareholding ratio of the largest shareholder and accounting conservatism}

First of all, we would like to caution against conflating majority and control here. Large shareholders do not have to have a majority stake to control a company that is clearly defined by international accounting standards. Control might be exercised even at $35 \%$ shares held and even lower especially when the remaining shareholders own smaller portfolio and they not related to each other. Given that our study related to Chinese companies we ought to refer to Measures on the Takeover of Listed Companies issued by China Securities Regulatory Commission (CSRC) in 2008 which postulates that control takes place when the owner has substantial rights to alter the composition of the board, and therefore affect managerial decision making (CSRC China Securities Regulatory Commission, 2008). Moreover, provision 84 at chapter 10 of this act set the bar as to who can be regarded as controlling investor - shareholder who owns more than $30 \%$ of the company's shares (CSRC, 2008).

Controlling shareholders can significantly affect the company's activities, determine its strategy, including through the impact on management. The controlling shareholder has the necessary power to leave its footprints on the financial reporting process as well and eventually exploit accounting information to further its private interest (Cullinan et al., 2012). That is why we expect that companies having controlling shareholders demonstrate lower levels of conservatism.

Hypothesis 5: The shareholding ratio of the largest shareholder is negatively associated with accounting conservatism.

\section{Research design}

\subsection{Data selection and sampling}

We select China's listed information technology companies as the research sample. Period our study covers is from 2003 to 2019 and the rationale for it is the fact that the China Securities Regulatory Commission requires all listed companies to establish independent directors following regulations after June 30, 2003. In indicated time frame 
(2003 to 2019), there were 352 listed information technology companies in China, with a total of 2197 observations. Due to the fact that 43 companies have only one year of observations, so they are deleted, leaving our sample 309 companies large with 2154 firm-year observations. The observed values and percentages of each category are shown in Table 3.

\section{Table 3: Samples and observations}

\begin{tabular}{|c|c|c|c|c|}
\hline $\begin{array}{c}\text { Industry } \\
\text { Code }\end{array}$ & Sub-industry name & Firms & Observations & N\% \\
\hline 163 & $\begin{array}{c}\text { Telecommunications, broadcast television and satellite } \\
\text { transmission services }\end{array}$ & 37 & 207 & 9.61 \\
\hline 164 & Internet and related services & 93 & 441 & 20.47 \\
\hline I65 & Software and Information Technology Service Industry & 218 & 1,506 & 69.92 \\
\hline Total & 3 & 309 & 2,154 & 100.00 \\
\hline
\end{tabular}

In order to remove the influence of outliers on the regression results, after manually checking the outliers, we performed tailing processing for continuous variables at $1 \%$ and $99 \%$.

\subsection{Variables and measures}

\section{Dependent variable}

According to (Givoly \& Hayn, 2000), accounting conservatism can be calculated as follow:

$$
\text { AccCon }_{i, t}=\left(\mathrm{IBEXT}_{i, t}+\mathrm{DEP}_{i, t}-\mathrm{CFO}_{i, t}\right) \times(-1)
$$

where AccCon ${ }_{i, t}$ refers to accounting conservatism in firm $i$ at year $t, I_{B E X}, t$ refers to net income before extraordinary items, DEP $\mathrm{i}_{\mathrm{i}, \mathrm{t}}$ refers to depreciation expense and $\mathrm{CFO} \mathrm{i}, \mathrm{t}$ to cash flow from operating activities.

\section{Independent and control variables}

Independent and control variables deployed by the paper are given in table 4 .

Table 4: Variables Definition

\begin{tabular}{|c|c|c|}
\hline Variable & Abbreviation & Definition \\
\hline \multicolumn{3}{|c|}{ Dependent variables } \\
\hline $\begin{array}{c}\text { Account } \\
\text { conservatism }\end{array}$ & AccCon & Formula (1) \\
\hline \multicolumn{3}{|c|}{ Independent variables } \\
\hline $\begin{array}{l}\text { Management } \\
\text { shareholdings }\end{array}$ & ManOwn & Management shareholding/total share capital \\
\hline $\begin{array}{l}\text { Ownership } \\
\text { Concentration }\end{array}$ & Top1 & Shareholding ratio of the largest shareholder \\
\hline Board Size & BoardSize & Total number of board's members \\
\hline $\begin{array}{l}\text { Independent } \\
\text { directors ratio }\end{array}$ & INDR & Percentage of independent directors \\
\hline CEO Duality & Duality & $\begin{array}{c}\text { CEO duality, } 1=\text { Chairman and CEO are the same person, } 0= \\
\text { otherwise }\end{array}$ \\
\hline \multicolumn{3}{|r|}{ Control variables } \\
\hline & LnSize & Natural log of total assets \\
\hline & Leverage & Total liabilities / total assests \\
\hline
\end{tabular}




\section{Empirical model}

In order to test the influence of ownership structure and board characteristics on accounting conservatism, according to the model of Basu (1997), we constructed the following regression model:

$$
\begin{aligned}
& \text { AccCon }_{i, t}=\beta_{0}+\beta_{1} \text { ManOwn }_{i, t}+\beta_{2} \text { Inst0 }_{\text {wn }}, t, \beta_{3} \text { Topi }_{i, t}+\beta_{4} \text { BoardSize }_{i, t}+\beta_{5} \text { INDR }_{i, t}+ \\
& \beta_{6} \text { Duality }_{i, t}+\beta_{7} \text { AuditQ }_{i, t}+\beta_{8} \text { LnSize }_{i, t}+\beta_{9} \text { Leverage }_{i, t}+\beta_{10} \text { PBR }_{i, t}+u_{i, t}
\end{aligned}
$$

Ownership structure variables: ManOwn $n_{i, t}$ is the shareholding ratio of management, which is the board of directors, the board of supervisors and senior management; Top $1_{i, t}$ is the shareholding ratio of the largest shareholder.

Board characteristic variables: BoardSize $i_{i, t}$ is the number of board members including the chairman; INDR $\mathrm{i}, \mathrm{t}$ is the ratio of independent directors to the number of board members; Dualityit, is the separation of the roles of the chairman and the chief executive officer, when the chairman and CEO are the same person 1, other cases are 0.

Control variables: LnSize $e_{i, t}$ is the logarithm of the company's total assets at the end of the year; Leverage $e_{i, t}$ is the asset-liability ratio; Year $_{i, t}$ is the year of the data.

\section{Result and Discussion}

\subsection{Descriptive statistics and correlation analysis}

Table 5 presents the descriptive statistical results of all variables. According to formula (1), the positive sign of AccCon means that the company has more accounting robustness, and if it is negative, it means less accounting robustness. According to the results of descriptive statistics, the average value of accounting conservativeness in the information technology industry is 0.01 , which means that China's information technology industry is more inclined to accounting conservatism.

For independent variables, the board size of the information technology industry is between $3-17$, and the median is 9 . The average ratio of independent directors is $37.7 \%$, which is lower than the United States (Elshandidy \& Hassanein, 2014), but in China, it is the average for all industries (Yang \& Ko, 2019). The average management shareholding ratio is $22 \%$, which is much higher than that of Egypt (El-Habashy, 2019). The average shareholding ratio of the largest shareholder is $28.61 \%$, slightly higher than the average of other industries in China (Cullinan et al., 2012).

\begin{tabular}{|c|c|c|c|c|c|c|}
\hline Variable & Obs & Min & Max & Mean & Median & SD \\
\hline \multicolumn{7}{|c|}{ Panel A: Dependent variable } \\
\hline AccCon & 2147 & -0.232 & 0.953 & 0.010 & -0.012 & 0.152 \\
\hline \multicolumn{7}{|c|}{ Panel B: Continuous variables } \\
\hline BoardSize & 2145 & 3.000 & 17.000 & 8.452 & 9.000 & 1.907 \\
\hline INDR & 2145 & 0.308 & 0.571 & 0.377 & 0.364 & 0.052 \\
\hline ManOwn & 2102 & 0.000 & 0.703 & 0.220 & 0.158 & 0.224 \\
\hline Top1 & 2153 & 7.260 & 62.368 & 28.613 & 26.505 & 12.780 \\
\hline LnSize & 2154 & 18.157 & 24.457 & 21.315 & 21.238 & 1.145 \\
\hline Leverage & 2154 & 0.031 & 3.805 & 0.398 & 0.316 & 0.464 \\
\hline \multicolumn{7}{|c|}{ Panel C: Dummy variables } \\
\hline \multirow{3}{*}{ Duality } & & Dummy & & $\mathrm{N}$ & & Per cent $\%$ \\
\hline & & 0 & & 1326 & & 64.78 \\
\hline & & 1 & & 721 & & 35.22 \\
\hline
\end{tabular}

Table 5: Descriptive statistics 
Table 6 reports the results of the Pearson correlation test which shows that accounting conservatism is negatively correlated with the size of the board of directors, management's shareholding, the shareholding ratio of the largest shareholder, and the company size, and the correlation is significant. At the same time, accounting conservatism is positively correlated with the asset-liability ratio.

Table 6: Pearson Correlation Test

\begin{tabular}{|c|c|c|c|c|c|c|c|c|}
\hline & AccCon & BoardSize & INDR & Duality & ManOwn & Top1 & LnSize & Leverage \\
\hline AccCon & 1 & & & & & & & \\
\hline BoardSize & $\frac{-}{0.067^{\star \star *}}$ & 1 & & & & & & \\
\hline INDR & $0.040^{*}$ & $-0.531^{* * *}$ & 1 & & & & & \\
\hline Duality & -0.019 & $-0.155^{\star \star *}$ & $0.115^{* * *}$ & 1 & & & & \\
\hline ManOwn & $\stackrel{-}{-}^{-162^{* * *}}$ & $-0.188^{* * *}$ & $0.077^{* \star *}$ & $0.218^{\star \star \star}$ & 1 & & & \\
\hline Top1 & $0.089^{* * *}$ & $0.058^{\star \star \star}$ & 0.001 & $0.050^{* *}$ & 0.002 & 1 & & \\
\hline LnSize & $0.131^{* * *}$ & $0.203^{\star \star *}$ & -0.007 & $0.095^{* \star *}$ & $-0.186^{* * *}$ & $0.042^{* *}$ & 1 & \\
\hline Leverage & $0.519^{* * *}$ & $-0.052^{* *}$ & -0.012 & $-0.057^{* *}$ & $-0.280^{* * *}$ & $0 . \overline{0} 7^{* *}$ & $0 . \overline{-}^{-}$ & 1 \\
\hline
\end{tabular}

Table 7 reports the results of the panel data regression analysis. Before performing panel data regression, we did a Hausman test, $P<0.01$, so we used a fixedeffects model for panel data regression. Model 1 shows the relationship between board characteristics and accounting conservatism. Board size $(p<0.05)$, the proportion of independent directors $(p<0.05)$ and accounting conservatism are significantly positively correlated, while CEO Duality $(p<0.01)$ and accounting conservatism are significantly negatively correlated.

Model 2 shows the relationship between ownership structure and accounting conservatism. The shareholding ratio of management $(p<0.01)$ and the shareholding ratio of the largest shareholder $(p<0.01)$ are significantly negatively correlated with accounting conservatism. The three control variables company size $(p<0.01)$, asset-liability ratio $(p<0.01)$, and year $(p<0.01)$ are all significantly related to accounting conservatism.

Table 7: Panel Data Regression Results

\begin{tabular}{cccc}
\hline & $(1)$ & $(2)$ & $(3)$ \\
AccCon & AccCon & $0.007^{* *}$ \\
\hline BoardSize & $0.007^{* *}$ & & $(2.03)$ \\
INDR & $(1.98)$ & $0.248^{* *}$ & $(2.57)$ \\
Duality & $0.232^{* *}$ & & $-0.037^{* * *}$ \\
& $(2.40)$ & $(-3.98)$ & $-0.111^{* * *}$ \\
ManOwn & $-0.041^{* * *}$ & $(-3.21)$ & $-0.002^{* * *}$ \\
Top1 & $(-4.31)$ & $-0.138^{* * *}$ & $(-2.97)$ \\
LnSize & & $(-3.97)$ & $-0.038^{* * *}$ \\
Leverage & & $-0.002^{* * *}$ & $(-6.48)$ \\
& $-0.036^{* * *}$ & $(-3.25)$ & $0.212^{* * *}$
\end{tabular}




\begin{tabular}{cccc}
\hline Year & $0.008^{* * *}$ & $0.002^{*}$ & $0.005^{* * *}$ \\
& $(5.74)$ & $(1.65)$ & $(3.46)$ \\
\multirow{2}{*}{ cons } & $-14.907^{* * *}$ & -3.794 & $-9.783^{* * *}$ \\
& $(-5.72)$ & $(-1.46)$ & $(-3.31)$ \\
\hline $\mathrm{N}$ & 2034 & 2096 & 1987
\end{tabular}

Note: ${ }^{* * *},{ }^{* *}$ and ${ }^{*}$ indicate at $1 \%, 5 \%$ and $10 \%$ level of significance respectively.

The data presented above give green light to four of our hypotheses and reject one (table 8).

Table 8: Study's results at a glance

\begin{tabular}{|l|c|}
\hline \multicolumn{1}{|c|}{ Hypothesis formulation } & $\begin{array}{c}\text { Confirmation / } \\
\text { rejection of } \\
\text { hypothesis }\end{array}$ \\
\hline $\begin{array}{l}\text { Hypothesis 1: Board independence is positively associated with conservative } \\
\text { accounting }\end{array}$ & confirmed \\
\hline Hypothesis 2: Board's size is positively associated with conservative accounting & confirmed \\
\hline $\begin{array}{l}\text { Hypothesis 3: CEO duality is negatively associated with accounting conservatism } \\
\text { conservatism }\end{array}$ & confirmed \\
\hline $\begin{array}{l}\text { Hypothesis 5: The shareholding ratio of the largest shareholder is negatively } \\
\text { associated with accounting conservatism }\end{array}$ & confirmed \\
\hline
\end{tabular}

\section{Discussions and conclusions}

This article investigates corporate governance attributes and accounting conservatism using Chinese data. Five corporate governance attributes are examined: board independence, the board size, CEO duality, management shareholding, the shareholding ratio of the largest shareholder. Unlike many previous papers concentrated on rather one attribute (board characteristics or ownership structure) our study combines both board structure and ownership structure. Our sample includes 309 listed information technology companies in China, with a total of 2154 firm-year observations covering 2003 to 2019 years.

The results of this study are mixed as several findings go contrary to our expectation. Overall the majority of phenomenons we study behave in a way congruent with agency and stakeholder's theory. In fact, four out of five hypotheses are confirmed, while one is rejected. Our expectations on the significant positive association between board independence and board size are confirmed. The same holds for CEO Duality which we posited to be negatively associated with accounting conservatism. Our proposition in regards to the shareholding ratio of the largest shareholder is that it is significantly negatively correlated with accounting conservatism and our findings testify to that in Chinese listed companies' settings.

The suggested association concerning the shareholding ratio of management and accounting conservatism purports to be positive as we expect due to owning a share in company managers would to lesser degree manipulate with the earning as this decision implicates their wealth as owners as well. However, the findings point to the reversed verdict and postulate that the shareholding ratio of management significantly negatively correlated with accounting conservatism. 
Our results testify also to preposition put forward in the introduction that institutional settings play a role and the link between corporate governance attributes and accounting conservatism vary across jurisdictions. In contrast to previous studies that found either negative association between board size in Taiwan and Egypt (Chi et al., 2009; Nasr \& Ntim, 2018) or no association in common law countries like US, UK and Australia (Ahmed \& Duellman, 2007; Elshandidy \& Hassanein, 2014; Lim, 2011) this study reports the positive association. We found alongside with (Ahmed \& Henry, 2012; Elshandidy \& Hassanein, 2014; Nasr \& Ntim, 2018) who investigated companies from Australia, UK and Egypt that board independence is positively associated with conservative accounting as opposed to findings of (Ahmed \& Duellman, 2007) - negative association (US) and (Lim, 2011) - no association (Australia). CEO duality in our study as well as in that of (Lim, 2011; Nasr \& Ntim, 2018) who concentrated respectively on Egyptian and Australian companies negatively associated with accounting conservatism, whereas (Chi et al., 2009; Elshandidy \& Hassanein, 2014) on data from Taiwan and UK found positive association while (Ahmed \& Duellman, 2007) studying US companies found no association.

Congruent with prior results of (Cullinan et al., 2012) and confirming our hypothesis we find that the shareholding ratio of the largest shareholder is negatively associated with accounting conservatism. We posited that management shareholding is positively associated with accounting conservatism (we have not found prior similar research to compare it to our findings) although the result revealed the reversed connection.

This study had several limitations. First, we focus on and our sample consists of data only from one country. Therefore, it is only with caution our findings are to be extrapolated across other jurisdictions. Second, the accounting conservatism measurement indicators are subjected to some limitations. In our study, following many previous studies, we utilize only one measure of accounting conservatism although other measures available in the same already mentioned Basu model. Third, although we used several elements or features of corporate governance, namely the board's structure and ownership structure, the chances are that other features of corporate governance could bring other results. For example, our erstwhile intention was to include among ownership structure indicators share of intuitional ownership but due to insufficiency of data, this intention was dropped. We posit here that the more institutional investors come into the company and the greater the part of shares they own, the higher the level of accounting conservatism. Fourth, the endogeneity issue could not be controlled through the means of statistics. In other words, what is causality direction is still an open question. Is it from corporate governance to conservatism or the other way around? However, most of the studies we reviewed suggesting that causality course is from corporate governance to conservatism (Ahmed \& Duellman, 2007; García Lara et al., 2009; Lim, 2011; Nasr \& Ntim, 2018) the reversed direction is not altogether ruled out.

To negate those limitations it is advisable for the future studies to extend the pool of the accounting conservatism measurement, as well as corporate governance attributes, used simultaneously with a wider investigation of this association in other countries. 
Moreover, research to determine the optimal level of conservatism would be of great interest - something that to the best of our knowledge has not been done to date.

\section{References}

Adams, R. B., Hermalin, B. E., \& Weisbach, M. S. (2010). The Role of Boards of Directors in Corporate Governance: A Conceptual Framework and Survey. Journal of Economic Literature, 48(1), 58-107. https://doi.org/10.1257/jel.48.1.58

Ahmed, A., \& Duellman, S. (2007). Accounting conservatism and board of director characteristics: An empirical analysis. Journal of Accounting and Economics, 43(2-3), 411-437. https://doi.org/10.1016/j.jacceco.2007.01.005

Ahmed, K., \& Henry, D. (2012). Accounting conservatism and voluntary corporate governance mechanisms by Australian firms. Accounting \& Finance, 52(3), 631-662. https://doi.org/10.1111/j.1467-629X.2011.00410.x

Ali, M., \& Ayoko, O. B. (2020). The impact of board size on board demographic faultines. Corporate Governance: The International Journal of Business in Society, ahead-of-p(ahead-ofprint). https://doi.org/10.1108/CG-03-2020-0100

Barker, R., \& McGeachin, A. (2015). An Analysis of Concepts and Evidence on the Question of Whether IFRS Should be Conservative. Abacus, 51(2), 169-207. https://doi.org/10.1111/abac.12049

Basu, S. (1997). The conservatism principle and the asymmetric timeliness of earnings 1 . Journal of Accounting and Economics, 24(1), 3-37. https://doi.org/10.1016/S0165-4101(97)00014-1

Beaver, W. H., \& Ryan, S. G. (2005). Conditional and Unconditional Conservatism:Concepts and Modeling. Review of Accounting Studies, 10(2-3), 269-309. https://doi.org/10.1007/s11142-005-1532-6

Bolgorian, M., \& Mayeli, A. (2020). Accounting conservatism and money laundering risk. Accounting Research Journal, ahead-of-p(ahead-of-print). https://doi.org/10.1108/ARJ-12-2018-0221

Caskey, J., \& Laux, V. (2017). Corporate Governance, Accounting Conservatism, and Manipulation. Management Science, 63(2), 424-437. https://doi.org/10.1287/mnsc.2015.2341

Chi, W., Liu, C., \& Wang, T. (2009). What affects accounting conservatism: A corporate governance perspective. Journal of Contemporary Accounting \& Economics, 5(1), 47-59. https://doi.org/10.1016/j.jcae.2009.06.001

Chowdhury, S. D., \& Wang, E. Z. (2020). Board size, director compensation, and firm transition across stock exchanges: evidence from Canada. Journal of Management and Governance, 24(3), 685-712. https://doi.org/10.1007/s10997-019-09481-1

Chung, R., Firth, M., \& Kim, J.-B. (2003). Auditor conservatism and reported earnings. Accounting and Business Research, 33(1), 19-32. https://doi.org/10.1080/00014788.2003.9729629

CSRC (2008). China Securities Regulatory Commission. Measures for the Administration of the Takeover of Listed Companies. Retrieved from http://www.csrc.gov.cn/pub/zjhpublic/G00306207/200809/t20080926_34062.htm

Cullinan, C. P., Wang, F., Wang, P., \& Zhang, J. (2012). Ownership structure and accounting conservatism in China. Journal of International Accounting, Auditing and Taxation, 21(1), 1-16. https://doi.org/10.1016/j.intaccaudtax.2012.01.001

El-Habashy, H. A. K. (2019). The effect of corporate governance attributes on accounting conservatism in Egypt. Academy of Accounting and Financial Studies Journal, 23(3).

Elshandidy, T., \& Hassanein, A. (2014). Do IFRS and board of directors' independence affect accounting conservatism? Applied Financial Economics, 24(16), 1091-1102. https://doi.org/10.1080/09603107.2014.924291

García Lara, J. M., García Osma, B., \& Penalva, F. (2009). Accounting conservatism and corporate 
governance. Review of Accounting Studies, 14(1), 161-201. https://doi.org/10.1007/s11142-007-9060-1

García Lara, J. M., Osma, B. G., \& Penalva, F. (2007). Board of Directors' Characteristics and Conditional Accounting Conservatism: Spanish Evidence. European Accounting Review, 16(4), 727-755. https://doi.org/10.1080/09638180701706922

Gillan, S. L. (2006). Recent Developments in Corporate Governance: An Overview. Journal of Corporate Finance, 12(3), 381-402. https://doi.org/10.1016/j.jcorpfin.2005.11.002

Givoly, D., \& Hayn, C. (2000). The changing time-series properties of earnings, cash flows and accruals: Has financial reporting become more conservative? Journal of Accounting and Economics, 29(3), 287-320. https://doi.org/10.1016/S0165-4101(00)00024-0

Guay, W., \& Verrecchia, R. (2006). Discussion of an economic framework for conservative accounting and Bushman and Piotroski (2006). Journal of Accounting and Economics, 42(1-2), 149-165. https://doi.org/10.1016/j.jacceco.2006.03.003

Hermalin, B., \& Weisbach, M. (2003). Boards of Directors as an Endogenously Determined Institution: A Survey of the Economic Literature. FRBNY Economic Policy Review, 7-16. https://doi.org/10.3386/w8161

lyengar, R. J., \& Zampelli, E. M. (2009). Self-selection, endogeneity, and the relationship between CEO duality and firm performance. Strategic Management Journal, 30(10), 1092-1112. https://doi.org/10.1002/smj.776

Jensen, M. C. (1993). The Modern Industrial Revolution, Exit, and the Failure of Internal Control Systems. The Journal of Finance, 48(3), 831-880. https://doi.org/10.1111/j.15406261.1993.tb04022.x

Jensen, M. C., \& Meckling, W. H. (1976). Theory of the firm: Managerial behavior, agency costs and ownership structure. Journal of Financial Economics, 3(4), 305-360. https://doi.org/10.1016/0304-405X(76)90026-X

Khuong, N. V., Thu, P. A., Lieu, D. T. T., Anh, T. T. P., Giau, N. T. M., Han, N. M., \& Mo, N. K. (2020). Financial and Non-financial Factors Affecting Board Size of the Listed Firms in Vietnam. International Journal of Financial Research, 11(2), 187. https://doi.org/10.5430/ijfr.v11n2p187

Kukah, M. A., Amidu, M., \& Abor, J. Y. (2016). Corporate governance mechanisms and accounting information quality of listed firms in Ghana. African J. of Accounting, Auditing and Finance, 5(1), 38. https://doi.org/10.1504/AJAAF.2016.077599

Lim, R. (2011). Are corporate governance attributes associated with accounting conservatism? Accounting \& Finance, 51(4), 1007-1030. https://doi.org/10.1111/j.1467629X.2010.00390.x

Lobo, G. J., Robin, A., \& Wu, K. (2020). Share repurchases and accounting conservatism. Review of Quantitative Finance and Accounting, 54(2), 699-733. https://doi.org/10.1007/s11156019-00804-9

Moy, M., Heaney, R., Tarca, A., \& van Zyl, W. (2020). Conditional accounting conservatism: Exploring the impact of changes in institutional frameworks in four countries. Journal of $\begin{array}{llll}\text { Contemporary Accounting \& Economics, 16(3), } 100214 . & .\end{array}$ https://doi.org/10.1016/j.jcae.2020.100214

Mubeen, R., Han, D., Abbas, J., \& Hussain, I. (2020). The Effects of Market Competition, Capital Structure, and CEO Duality on Firm Performance: A Mediation Analysis by Incorporating the GMM Model Technique. Sustainability, 12(8), 3480. https://doi.org/10.3390/su12083480

Nasr, M. A., \& Ntim, C. G. (2018). Corporate governance mechanisms and accounting conservatism: evidence from Egypt. Corporate Governance: The International Journal of Business in Society, 18(3), 386-407. https://doi.org/10.1108/CG-05-2017-0108 
Nguyen, T. T., Duong, C. M., Nguyen, N. T. M., \& Bui, H. Q. (2020). Accounting conservatism and banking expertise on board of directors. Review of Quantitative Finance and Accounting, 55(2), 501-539. https://doi.org/10.1007/s11156-019-00851-2

Ozbek, O. V., \& Boyd, B. (2020). The influence of CEO duality and board size on the market value of spun-off subsidiaries. Journal of Strategy and Management, 13(3), 333-350. https://doi.org/10.1108/JSMA-03-2019-0039

Rajan, M. V., Reichelstein, S., \& Soliman, M. T. (2007). Conservatism, growth, and return on investment. Review of Accounting Studies, 12(2-3), 325-370. https://doi.org/10.1007/s11142-007-9035-2

Shleifer, A., \& Vishny, R. W. (1986). Large shareholders and corporate control. The Journal of Political Economy, 94, 461-488.

Sterling, R. R. (1967). Conservatism: The Fundamental Principle of Valuation in Traditional Accounting*. Abacus, 3(2), 109-132. https://doi.org/10.1111/j.1467-6281.1967.tb00375.x

Vitolla, F., Raimo, N., \& Rubino, M. (2020). Board characteristics and integrated reporting quality: an agency theory perspective. Corporate Social Responsibility and Environmental Management, 27(2), 1152-1163. https://doi.org/10.1002/csr.1879

Watts, R. L. (2003). Conservatism in Accounting Part I: Explanations and Implications. Accounting Horizons, 17(3), 207-221. https://doi.org/10.2308/acch.2003.17.3.207

Watts, R. L. (2006). What has the invisible hand achieved? Accounting and Business Research, 36(sup1), 51-61. https://doi.org/10.1080/00014788.2006.9730046

Xie, B., Davidson, W. N., \& DaDalt, P. J. (2003). Earnings management and corporate governance: the role of the board and the audit committee. Journal of Corporate Finance, 9(3), 295316. https://doi.org/10.1016/S0929-1199(02)00006-8

Yang, L., \& Ko, P. (2019). The Empirical Study of Shareholding Structure and Firm Performance in China. In Proceedings of the 5th International Conference on Economics, Management, Law and Education (EMLE 2019). Paris, France: Atlantis Press. https://doi.org/10.2991/aebmr.k.191225.024 